\title{
"Wee have Tidings out of Polonia" English Corantos, News Networks, and the Polish-Lithuanian Commonwealth $^{1}$
}

\author{
Anna Kalinowska
}

In the latest study of London's news press during the Thirty Years' War, Jayne E.E. Boys - having inspected the datelines of the English corantos - argues, rightly, that as far as news transmission in early modern Europe is concerned, news generally tended to travel towards England through the Continent in a north-westerly direction. This statement is followed by a more detailed analysis of the issue:

The oldest news came from the central and eastern Habsburg lands and from Italy and Constantinople. German news came next. The freshest news was usually Dutch, though news from France, the Spanish Netherlands and Westphalia, when it was available, was seldom more than few days older and was often added at the end. News from places north of the Netherlands, such as Denmark and Sweden appeared less frequently, and via a variety of routs, but the activities of Danish and Swedish troops in Germany were eagerly reported. ${ }^{2}$

Surprisingly, in this description, Boys completely ignores the largest European state of the period, the Polish-Lithuanian Commonwealth, even though there are nearly 200 reports coming from or dealing with Poland-Lithuania, containing more than 250 news items, between 1620 and $1641 .^{3}$ This may be an unimpressive number when compared with, for example Germany or the Netherlands, but it is definitely enough to argue that, in spite of the geographical distance, the coranto readers were not only aware of Poland-Lithuania's

1 The research for the article was made possible by funding from The National Science Centre (project number N N108 148539).

2 Jayne E.E. Boys, London's News Press and the Thirty Years War (Woodbridge: The Boydell Press, 2011), p. 43.

3 The earliest report referring to Poland that I have managed to identify was published in late December 1620, while the last one comes from January 1641, although it is possible that there was some Polish news printed between 1618 and 1620. 
existence, but also were in a position to form their own opinions on this country based on what they had read in these publications.

The aim of this chapter is to analyse these reports and answer two main questions. Firstly, about their contents and the contexts in which the PolishLithuanian Commonwealth was presented to the English readers, and secondly about this country's place in the early European news networks used by the coranto editors.

Before starting this analysis one must stress the low survival figures for the news press publications from this period, the decline in publishing of news in the late 1620s, and Charles I's ban on corantos issued in late 1632. Due to these factors, in the case of Poland-Lithuania one can use a quantitative approach in only a very limited way, which would be more to trace general trends than to take advantage of it as an accurate research method for detailed queries. For example, the gap generated by the ban of 1632 means that we have no reports dealing with the war with Muscovy that started that year, which makes it very difficult to show in a reliable way how Polish-Muscovite relations were described by the corantos during the more than 20 year period we are interested in. Similarly, it seems almost impossible to make any strong arguments based on comparisons of the numbers of reports and the frequency with which the news from PolandLithuania and other countries was published. That is something that can be done by the researchers dealing with some of the 1650s newsbooks and the London Gazette as they have complete sets of numbers at their disposal.

It is still possible, however, to follow the main topics that reappear in subsequent reports and which unquestionably played an important role in the presentation of Poland-Lithuania to the English reading audience. Out of 254 identifiable news items, nearly half (122) dealt with military issues; 98 focused on politics (of which 48 dealt with diplomacy); 6 on religious problems; 5 on economy; and 23 did not belong to any of these categories. This basically means that when we look at the reports as a whole we can see the massive domination of information on military and diplomatic topics.

This, however, is not surprising. Firstly because these were exactly the type of newsworthy events favoured by the early modern press. ${ }^{4}$ Secondly, as is generally agreed, the Thirty Years' War was one of the main triggers for the development of, and was the main subject covered by, the early English news press. ${ }^{5}$ The Polish-Lithuanian state, although officially neutral, was in fact politically

4 Barbara J. Shapiro, A Culture of Fact: England, 1550-1720 (Ithaca and London: Cornell University Press, 2000), p. 87.

5 The English public became particularly interested in developments on the Continent when in 1618 the Estates of Bohemia elected James I's son-in-law, Frederick, as their king. Conflict 
and militarily involved in the conflict. As a result, its military and political relations with the Habsburgs, Sweden, the Ottoman Empire, and other neighbours had a significant impact on the situation in East Central Europe in the 1620s and early 1630s, and therefore were important for Frederick V's supporters.

Nearly half of all the military news dealt with Poland-Lithuania's conflicts with Turkey and the Tartars, which can be partly explained by the fact that the conflict reached its peak exactly at the same time that corantos were becoming more popular. In addition, the survival rate for this particular period, i.e. the early 1620s, is relatively good. As early as December of 1620, the corantos informed their readership of the Polish defeat at Cecora, ${ }^{6}$ while in September 1623 the readers could learn that the Turkish army had:

already plundered the Country for the space of a hundred miles together, doing so much mischief, as the Polish Chronicles have no example of so much misery done in any one Invasion, and the number of Polish losses exceeded 20 thousand people. ${ }^{7}$

The Tartars, who usually were the Sultan's closest allies, were also present in the reports as an important factor in Polish-Turkish relations. ${ }^{8}$

in Bohemia developed into the Thirty Years' War and, with a longer perspective, also affected the internal situation of the Stuart monarchy. See Joad Raymond, Pamphlets and Pamphleteering in Early Modern Britain (Cambridge: Cambridge University Press, 2003), pp. 130-138; Boys, London's News Press, pp. 1-32, 63-91; Joad Raymond, "News" in Joad Raymond (ed.), The Oxford History of Popular Print Culture: Volume One: Cheap Print in Britain and Ireland to 1660 (Oxford: Oxford University Press, 2011), pp. 380-383; id., The Invention of the Newspaper: English Newsbooks 1641-1649 (Oxford: Oxford University Press, 2005), pp. 6-13; Folke Dahl, "Amsterdam: Cradle of the English Newspapers", The Library, 5th series, 4 (1949), pp. 166-178; Sheila Lambert, "Coranto printing in England: the First Newsbooks", Journal of Newspaper and Periodical History, 8 (1992), pp. 3-19; Michael Frearson, "London Corantos in the 1620s", Studies in Newspaper and Periodical History, 1 (1993), pp. 3-17; id., "The Distribution and Readership of London Corantos in the 1620s" in Robin Myers and Michael Harris (eds.), Serials and Their Readers, 1620-1914 (New Castle, Del.: St Paul's Bibliographies, 1993), pp. 1-25. The most important bibliography of the corantos is still Folke Dahl, A Bibliography of English Corantos and Periodical Newsbooks, 1620-1642 (London: Bibliographical Society, 1952). In the following notes all corantos are identified by the first part of the title, date of publication, and (in brackets) the number in Dahl's Bibliography.

6 Corrant out of Italy, Germany, \&c., 23 December 1620 (Dahl 2), p. 1.

7 Weekely newes, 17 September 1623 (Dahl 128), p. 7. The report estimated that the TurkishTartar troops had also captured 30 thousand head of cattle and a significant number of horses.

8 A relation of letters and other advertisement of newes..., 27 September 1622 (Dahl 78), p. 10. 
Between 1620 and 1624 alone there are more than 50 stories (both shorter and longer) about Turkish and Polish troop movements, the Sultan's military preparations for another campaign against Poland, and rumours of a possible date or reasons for the attack. But what proves that the subject would have been truly popular with the readers is the fact that in early 1622 , editors decided to print a whole number entirely dedicated to recent events in the PolishTurkish war and including detailed reports on the siege of Chocim (where the highest ranking commanders of the Polish army and the oldest son of the Polish king, Prince Wladyslaw, tried to stop the Turkish invasion). Within a few months there was another monographic number printed, dealing this time with the internal situation in the Ottoman Empire, and stressing the importance of relations with Poland-Lithuania for that country. ${ }^{9}$

Interestingly, Poland-Lithuania was very often presented in those earliest publications as the first line of defence against a Muslim invasion of Europe and still in imminent danger of being attacked. This suggests that the idea might have become popular in England earlier than it has been hitherto believed; it has been commonly considered to be a stereotypical perception of the PolishLithuanian state in Western Europe in the late seventeenth century. ${ }^{10}$

With time however, corantos started to put this conflict into a more diverse context. For example, they implied that another Polish-Turkish war could hamper the ability of Bethlen Gabor, Prince of Transylvania and opponent of the Emperor, to fight against the Habsburgs, as he would be supported militarily by the Sultan only when the latter was not involved in another conflict with Poland-Lithuania."

Bethlen Gabor was also presented as an important factor in Turkish-Polish diplomatic relations - in 1624 it was reported that the Sultan's chaush warned

$9 \quad$ The first of these publications was Newes from Turkie and Poland (Dahl 35), and the other is The strangling death of great Turke and his two sonnes, 15 July 1622 (Dahl 58).

10 One of the corantos even referred to Poland-Lithuania as "the Bulwarke of Christianity": The strangling death of great Turke, 15 July 1622 (Dahl 58), sig. B3. This may be connected to the growing interest in relations between the Ottoman Empire and Christian Europe that was encouraged in England by regular commercial contacts with Turkey, publication of travel accounts, and also by the Polish diplomatic mission of Jerzy Ossoliński, who in London in 1621 sought military assistance against the Turks. Politically, Ossoliński's mission was not greatly successful, but it definitely contributed to, or was possibly even the watershed moment for the way Polish-Turkish relations were perceived in England. I am grateful to Dr Martyna Mirecka for a discussion on this subject and for bringing it to my attention.

11 Newes from the Palatine, [early March?] 1622 (Dahl 36), p. 22; More newes of the good successe..., 29 July 1623 (Dahl 122), p. 2. 
Sigismund III that if he provided the Emperor with any military support against Gabor, Poland-Lithuania would be immediately attacked by the Turks. ${ }^{12}$ The Transylvanian ruler's military plans as regards Poland were reported again when, in 1625, Bethlen Gabor became the brother-in-law of Gustavus Adolphus, the king of Sweden. It was expected then that Gabor would now attack Poland from the South to help Gustavus Adolphus who was engaged in a war against Sigismund III in Prussia, and this possible turn of events was suggested by a series of reports published in the mid-1620s. ${ }^{13}$

The way in which this Swedish-Polish conflict - dragging on since the late sixteenth century and originating in a dynastic rift between two lines of the Vasa family - was described by the corantos had also evolved. While in 1621 the coverage of the war in Livonia was limited to a few reports and concentrated solely on military aspects, ${ }^{14}$ that of the war in Prussia of 1626 was much more detailed and definitely pro-Swedish in its tenor. For example, in July 1626 one of the corantos described at length the capture of Marienburg (Malbork) by Gustavus Adolphus's army, as well as other spectacular successes of the Swedish forces, and informed the readers of their good morale and planned recruitment of further troops..$^{15}$ What is more, as early as April 1623, the issue was discussed in the context of the likelihood of Gustavus Adolphus's involvement in the war in Germany - on one hand it became apparent that in the case of a war with Poland, he would not be able to support the Protestants militarily, on the other, Sigismund was identified as one "who is in the Catholicke league," and so to some extent, the war could harm the Catholic camp. ${ }^{16}$

As has already been explained, very little can be found in the corantos about Poland-Lithuania's military conflict with her third neighbour, Muscovy, although the corantos did publish some reports suggesting the possibility of the breaking of the truce by the Russians, ${ }^{17}$ and their efforts to build an antiPolish military coalition with the Sultan. ${ }^{18}$

12 Newes from Europe: with particular accidents, 19 March 1624 (Dahl 142), p. 8.

13 E.g. in The continuation of our weekly newes..., 29 August 1626 (omitted by Dahl), p. 3.

14 Corrant out of Italy..., 21 January 1621 (Dahl 4), p. 2; The courant out of Italy..., 6 September 1621 (Dahl 13), p. 2; The courant out of Italy..., 18 September 1621 (Dahl 16), p. 2; Corant or weekly newes..., 11 October 1621 (Dahl 33), p. 1; Corant or weekely newes..., 22 October 1621 (Dahl 34), p. 2.

15 The continuation of our weekly newes..., 29 August 1626 (omitted by Dahl), pp. 2, 7.

16 A relation of the last newes from severall parts of the world, 8 April 1623 (Dahl 105), p. 18.

17 See for example, The newes of this present weeke..., 12 May 1623 (Dahl 111), p. 9.

18 A relation of the late horrible treason..., 19 February 1623 (Dahl 99), p. 27; The continuation of our former newes, 24 April 1623 (Dahl 108), pp. 11-12; A relation of Count Mansfields last proceedings..., 26 May 1623 (Dahl 113), p. 20. 
The corantos also ran a number of reports on the activities of Polish military units, the so-called Lisowczycy, sent by Sigismund III as assistance for the Emperor in his war against Frederick V and his supporters. "The Cossaks," as the editors referred to them, were very often described as unruly "inconvenient guests" looting huge areas of the Habsburg lands, from Moravia and Silesia to Austria. "We are daily ruined here by the Polonians," wrote one of the correspondents from Brin in Austria in September 1623, and this tearful complaint was not unique, with similar ones published on a regular basis. ${ }^{19}$ Their movements, news of further recruitments, and even rumours about their possible plans or routes were discussed and described in full detail in more than 30 reports. This should be not surprising as they were directly connected to the military situation in Germany. All these reports, although dealing mostly with military aspects, were also a clear illustration of not only the close military alliance but also the political accord between the Polish king and the Habsburgs.

The second largest grouping of news coming from or dealing with PolandLithuania covers political topics, including Poland-Lithuania's diplomatic relations with other states, her current domestic politics, and the functioning of the country's political system in general. Again, we can observe some strong disparity in reporting, since as was already mentioned, nearly half of the news items dealing with political issues concentrated on diplomacy.

The activities of Polish diplomats abroad, from The Hague, through Vienna, to Constantinople, ${ }^{20}$ were generally covered more comprehensively than those of foreign ambassadors in Poland-Lithuania. However, in February 1625, The continuation of our weekly news did carry a report about an imperial ambassador's commission to negotiate in Warsaw for the recruitment of 60 thousand Cossacks who were planned to be sent to the Low Countries. ${ }^{21} \mathrm{~A}$ similar report dealt with Tartar Chan's ambassador who was sent to Sigismund III with a mission to obtain the king's support against Turkey. ${ }^{22}$

All these reports were quite similar to those dealing with diplomatic relations between other countries, and focused on the diplomats' movements, the details of negotiations (if known or guessed), and ceremonial aspects, etc. The reports were rather superficial, although in the case of one mission, Krzysztof Zbaraski's

19 Our last weekely newes, 11 October 1623 (Dahl 131), pp. 13, 3; The suprisall of two Imperial towns..., 19 July 1622 (Dahl 61), pp. 3-4; A coranto. Relating divers particulars..., 7 November 1622 (Dahl 86), p. 8.

20 Courant newes out of Italy..., 15 July 1621 (Dahl 11), p. 2; Corante, or, newes from Italy..., 9 July 1621 (Dahl 22), p. 2; The continuation of our weekly newes..., 21 April 1625 (Dahl 169), p. 4; The continuation of our weekly newes..., 27 April 1625 (Dahl 170), p. 9.

21 The continuation of our weekly newes, 1 February 1625 (Dahl 162), p. 8.

22 The continuation of our weekly newes, 7 April 1725 (Dahl 167), p. 13. 
embassy to Turkey, we deal with excellent, detailed coverage. The English readers learned that the Polish diplomat's arrival was impatiently expected in Constantinople, but also that he, surprisingly, had some problems with acquiring a passport, and that his secretary - who had arrived earlier to prepare his visit - was executed in revenge for a recent Cossack incursion into Turkish territory. When the ambassador finally reached the capital, his entry was described by two different reports; according to the one sent from Venice, he was accompanied by 500 horsemen and 1000 musketeers, while the other told of 800 "divers Noble and Gentlemen of his Countrey." His problematic relations with the Sultan's officials were also described, but finally the corantos were able to confirm his success and the ratification of the peace by the Turks. ${ }^{23}$

As far as Polish-Lithuanian domestic politics is concerned, it was usually covered in a surprisingly detailed way. One can easily recognize that it was represented as strongly polarized and turbulent, not only due to current events, but also the very specific character of the country's political system, which featured an elected monarch. In the 1620s, a series of reports dealing with the relationship between the king and his subjects indicated clearly that the gentry - who as a group enjoyed a special position - largely opposed the monarch's ambitions to recover his hereditary kingdom (Sweden) and his support for the Habsburgs, and that therefore Sigismund III was facing:

a great danger of tumults at home in Poland as being troubled with [a] factious populace, who in the Elective kingdom [is] still chalanging the power to call their Kings to account. ${ }^{24}$

Similarly, a few months later, one of the reports stated that there was no chance that the king could change his subjects' attitude, as:

Nor the Gentry and Noble men of Poland are so easily commanded, or obsequiously addicted to their Princes, as in absolute Monarchies, where either their tenures tye them to observation or their duties and loyalties compell them to allegiance. ${ }^{25}$

23 See for example, Count Mansfields proceedings since the last battaile..., 9 September 1622 (Dahl 74), p. 1; Newes from most parts of Christendome, 25 September 1622 (Dahl 77), pp. 1, 15; Briefe abstracts out of divers letters of trust, 28 November 1622 (Dahl 89), p. 3; Weekly newes..., 30 January 1623 (Dahl 96), p. 2; The newes of this present weeke, 12 May 1623 (Dahl 111), p. 5.

24 The continuation of our former newes, 24 April 1623 (Dahl 108), p. 12.

25 The wonderfull resignation of Mustapha and the advancing of Amarath..., 11 November 1623 (Dahl 133), p. 7. 
When describing the way the Polish Parliament (Sejm) worked, the corantos presented a very similar picture - parliamentary sessions were often described as an arena of conflict between the king and his subjects, who opposed both his domestic and foreign policies. These reports are usually very detailed. Not only did they discuss the main issues debated by the members of both Houses, but on some occasions provided a very specific description of the events. In the spring of 1625 for example, readers learned that after another unsuccessful attempt to obtain the Sejm's consent for an official alliance with the Habsburgs, the king fell ill and at 11 o'clock at night finally left the session; the Parliament, due to his absence in the final hours, ended without making any binding decisions. ${ }^{26}$

A series of very interesting reports on Polish political life was also published in 1632 in relation to Sigismund's death. ${ }^{27}$ The event did not seem to have been a surprise due to the king's advanced age and deteriorating health, and one coranto even introduced the news of his decease with the words:

those of Polonia have for so long disputed of the succession of their King, that at the last they have found a reason of resolving the succession by his death. ${ }^{28}$

Apart from describing the late king's last days in a very detailed and usually reliable way, all these accounts discussed the possible future turn of events during the imminent royal election. Almost all indicated that Prince Wladyslaw, Sigismund's oldest son, was most likely to prevail, although they also mention Gustavus Adolphus and Archduke Leopold as serious contenders. Within a few weeks, it was Wladyslaw who, according to the corantos, became practically the only candidate able to get enough supporters to win the election. This was not only due to his personal popularity but also his close relation with the Protestant faction, to whom he had supposedly promised to protect their freedom of confession. ${ }^{29}$ This was only partly true, but when Wladyslaw was elected, it sealed to some extent the picture of a new Polish ruler who had been presented by the corantos of the 1620s as being in complete opposition to his staunchly Catholic father, and a person trying to smooth the religious tensions of the country. He was, for example, indicated as a mediator between some leaders of the Protestant opposition and his father

26 The continuation of our weekly newes..., 5 May 1625 (Dahl 171), p. 13.

27 The continuation of our forrine avisoes, 6 June 1632 (Dahl 274), p. 2.

28 The continuation of our forraine avisoes, 23 June 1632 (Dahl 277), p. 3.

29 The continuation of our Swedish intelligence, 1 September 1632 (Dahl 291), p. 7. 
when they demanded that the Catholic Church should be stripped of some illegally obtained estates. ${ }^{30}$

The greatly detailed character of the reports dealing with Poland-Lithuania's political life and its unique institutions, like Sejm or royal election, might suggest that they attracted special attention in Europe and that the news networks did try to respond by providing comprehensive coverage of the way they operated. In England this political interest might also have been piqued by the complex relationship between James I and his Parliaments.

On the other hand, the religious situation in Poland-Lithuania, which could also have been of interest for English readers, was discussed by the corantos in a very different way; the number of news items on this subject is surprisingly scarce (only 6), and they were usually much less detailed. In the 1620s we find some reports on attempts of the Polish Protestant lords to strengthen their position, for example by demanding the expulsion of the Jesuits, who were according to a report from 1622 - extremely unpopular in the country and who were also accused of preaching that the killing of a heretic, i.e. a Protestant, was not a sinful act. ${ }^{31}$ There was also a story about St. Peter and St. Paul's Church - a Lutheran church in Danzig (Gdańsk) - mentioning that Sigismund was supposed to have transferred it to one of the Catholic orders, although in fact the church ended up in Calvinist hands. ${ }^{32}$ This emphasizes the deep religious fractures and the government's attempts to preserve Catholic domination and to diminish further the influence of the Protestants.

As with religious matters, only a very limited number of reports included news on economic issues. These were mostly complaints about the difficult economic situation and the decline of commerce in some regions of the country, usually caused by the devastation of war. ${ }^{33}$ In 1622 there was a slightly

30 Weekly newes from..., 14 March 1623 (Dahl 103), p. 8. On one occasion, however, Wladyslaw was presented in a completely different light; during his European tour in 1624-1625, reports describing his visits to Brussels, Vienna, and Rome were clearly emphasizing the close links of the Polish Vasas to the Habsburgs and the Papacy. Moreover, the prince was even a victim of some false accusations when a story of his visit to the Spanish camp at Breda and a failed military adventure during which he allegedly lost more than 3000 Spanish soldiers, was run by one of the corantos. This could have been an attempt to use the Polish prince's presence at Breda for propaganda reasons. The continuation of of [sic] the weekly newes..., 22 September 1624 (Dahl 150), pp. 11-12.

31 A tr[ue] relati[on] of the pro[cee]dings of the Bavarian and Spa[nish] forces, 11 July 1622 (Dahl 57), pp. 5, 11; The suprisall of two Imperial towns..., 19 July 1622 (Dahl 61), p. 7.

32 A relation of this weekly newes, 22 October 1622 (Dahl 82), p. 10.

33 More newes of the affairs of the world, 10 June 1623 (Dahl 115), p. 5; The continuation of our weekly newes..., 29 August 1626 (omitted by Dahl), pp. 2, 7. 
more optimistic piece of news, when it was indicated that merchants from Lviv (Lwów) made huge profits by selling a substantial amount of grain to Constantinople. ${ }^{34}$ In some other cases information that could actually be of great importance, for instance to readers interested in Baltic trade, could be found in reports describing military operations, parliamentary sessions, etc. For example, in 1627 readers learned that Gustavus Adolphus, who had entered the city of Elbing (Elblag), ${ }^{35}$ planned to improve the conditions of the local port by redirecting the Vistula River so it could become a major commercial centre. ${ }^{36}$ Similarly, in late 1624 , reports on plans to call a Parliament suggested that one of the problems to be discussed during its session would be the depreciation of the Polish currency. ${ }^{37}$

Even less attention was paid by the corantos to providing their readers with Polish news on natural disasters, famines, etc. An example of this kind of news was printed only once, in the summer of 1622 , and it dealt with the tragic fire that had destroyed the Cathedral in Poznan. ${ }^{38}$ In some other cases, famine, for example, was given as an explanation for some other events - in 1624 starving Tartars were supposed to be moving towards Poland-Lithuania as they were not able to feed themselves and their families in their country. ${ }^{39}$ This absence may be considered to be quite surprising, as these kind of topics were usually popular in the early modern press, but on the other hand, corantos in general very seldom ran such stories. ${ }^{40}$

What factors determined that the structure of news dealing with or coming from Poland-Lithuania looked this way? One of the most important was undoubtedly the place of origin of reports used by the editors. The map (Map 2.1), shows all the cities where more than 3 reports were datelined from, and selected cities where 1 or 2 reports originated. It shows that the highest numbers of reports were provided by the major European news hubs, such as Vienna, Prague, and Venice. Among the cities that were named as a place of origin of a dozen or more reports, one can also find Breslau (Wrocław) and Danzig - centres of relatively secondary importance for the pan-European

34 A tr[ue] relati[on] of the pro[cee]dings of the Bavarian and Spa[nish] forces, 11 July 1962 (Dahl 57), p. 6.

35 The continuation of our weekly newes..., 29 August 1626 (omitted by Dahl), pp. 2, 4.

36 The continuation of our weekly newes..., 10 July 1627 (omitted by Dahl), sig. A2.

37 The two wonderful and lamentable accidents..., 11 October 1624 (Dahl 392), p. 2.

38 A relation of many memorable..., 14 September 1622 (Dahl 75), p. 9.

39 The continuation of the weekly newes..., 16 September 1624 (Dahl 149), pp. 4-5.

40 Maria Bogucka, "The Destruction of Towns by Natural Disaster as Reported in Early Modern Newspapers" in M. Bogucka (ed.), Baltic Commerce and Urban Society 15001700: Gdansk/Danzig and Its Polish Context (Aldershot: Ashgate, 2003), p. 311. 


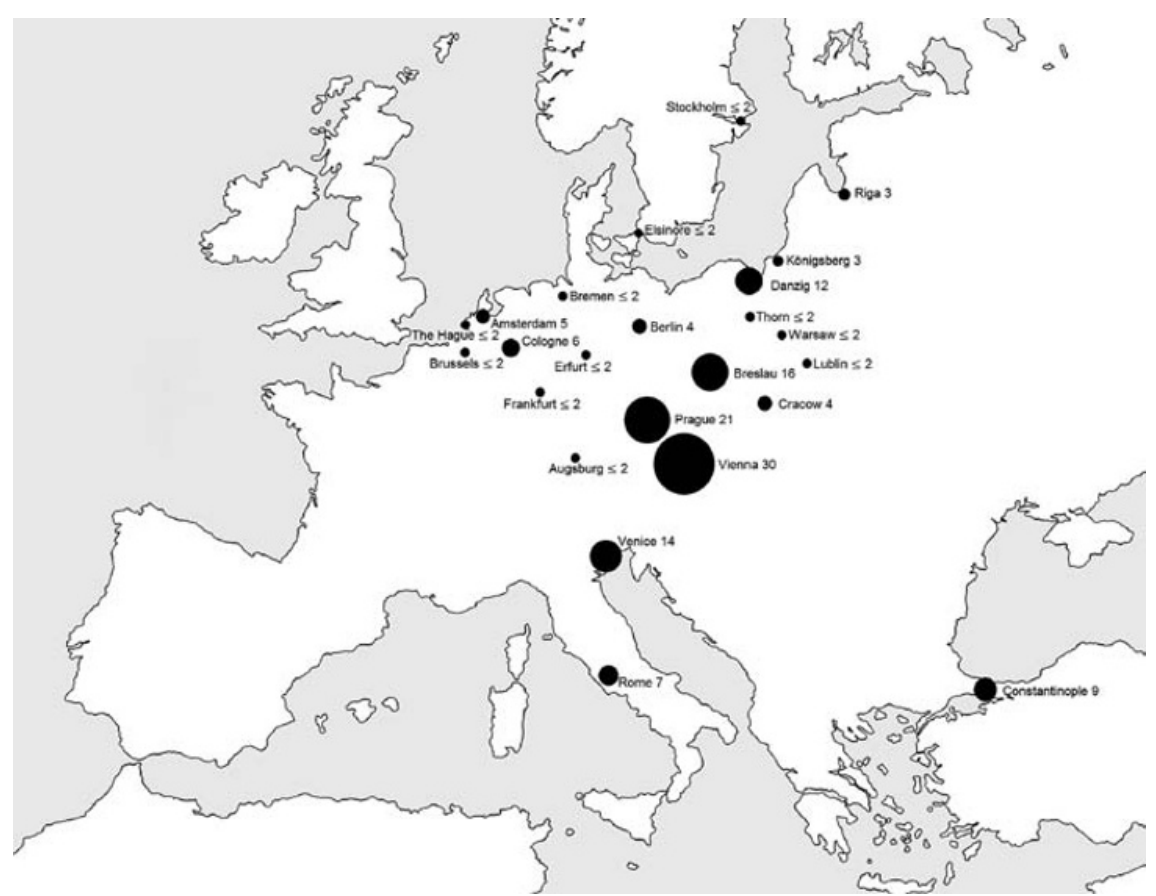

MAP 2.1 Distribution of datelines

information network but, in the case of Breslau, crucial for channeling news from territories east of the Habsburg borders, and Danzig, crucial as the main news centre of the whole Baltic region. Among the cities that provided between 3 and 12 reports, one can identify both large news hubs like Amsterdam and Rome, and lesser cities like Berlin and Riga. There were also 9 reports sent directly from Constantinople, although some of the information on TurkishPolish relations was channeled through Venice as well. The list of cities that provided only a diminutive number of reports includes Elsinore and Stockholm in Scandinavia, but also, among others, Frankfurt and Bremen in Germany, and The Hague in the Netherlands.

As far as the 28 reports coming directly from Poland-Lithuania are concerned, we see, unsurprisingly, the importance of Danzig (12 reports, which is more than $40 \%$ of the total number). Cracow, and generally "Poland," were identified as the origin of 4 reports each, while only 2 reports were sent from the capital - Warsaw. No reports originated in Lithuania (although the country was mentioned in 1622 when one of the reports was datelined as coming from "Riga in Lithuania," although this was an error as Riga was then a part of Livonia and, by 1622 was already under Swedish control). 
As we can see, the ratio of reports from the 3 Habsburgs cities (Vienna, Prague, and Breslau) to those originating directly from Polish-Lithuanian territory is nearly 2.5 to 1, which clearly indicates that it was the Habsburg Empire's news network that played a critical role in providing English editors with news both from, and dealing with, Poland-Lithuania. This can explain the large number of news items dealing with the activities of Polish military units in the Empire, coverage of the actions of Polish diplomats in Vienna, Sigismund III's military plans, and reports on Bethlen Gabor, whose relationship with Poland was relatively important for the Emperor.

The prominent position of Venice can be explained by its role as the major news hub channeling reports from the Levant, while Constantinople owed its place to the fact that the editors had direct access to materials provided by the English ambassador in Constantinople, Sir Thomas Roe, who was personally involved in Polish-Turkish negotiations and was a strong supporter of England's possible cooperation with Bethlen Gabor. ${ }^{41}$ One must also remember, that as far as Italian news (both from Venice and Rome) is concerned, there was a traditional postal route between these cities and Antwerp, which was one of the most important news hubs providing coranto editors with continental news. ${ }^{42}$ This, combined with the fact that the best surviving run of corantos comes from the early 1620s, when Poland-Lithuania and Turkey were involved in a war, helps clarify why we deal with such a significant number of reports about military conflicts between these two countries.

What is surprising is how relatively few reports referring to events in Poland-Lithuania came from the Baltic cities and, consequently, how little the

41 Paul Arblaster, "Posts, Newsletters, Newspapers: England in a European system of Communications" in J. Raymond (ed.), News Networks in Seventeenth-Century Britain and Europe (London and New York: Routledge, 2006), p. 24. In July 1622, Roe was named as a source of news reports in A true relation of the murder of Osman the great Turke, 4 July 1622 (Dahl 56), p. 4, but there are also some other indications for his cooperation with the editors. For example, in one of the corantos describing the Polish-Turkish conflict and later the peace negotiations, it was stated that the information the publication included came from "a Latin copie written by a gentleman of quality, who was an actor in all the businesse", Newes from Turkie and Poland..., s.d. (Dahl 35), p. 1. As Roe was, in this period, directly involved in Polish-Turkish negotiations, he seems the most likely person to be this gentleman, see, Anna Kalinowska, "Rzeczpospolita $w$ dziatalności ambasadora angielskiego w Konstantynopolu sir Thomas a Roe, 1621-1628” in R. Skowron (ed.), Polska wobec wielkich konfliktów $w$ Europie nowożytnej. $Z$ dziejów dyplomacji i stosunków międzynarodowych (Kraków: Societas Vistulana 2009), p. 310.

42 Wolfgang Behringer, "Communications Revolutions: A Historiographical Concept", German History, 24 (2006), p. 350; Boys, London's News Press, p. 42. 
corantos reported on the Baltic trade and economic situation in East-Central Europe, even though it was so important for England. This seems to have resulted from the fact that the Eastland merchants might have been able to use their own specialized news networks that provided them with information critical for conducting their business, but for some reason were not interested in sharing it with a wider audience. There is limited evidence to support this theory as only scarce sources documenting their work were preserved. However, there is no doubt that because of the scale of commercial activities and the complicated situation in the region, they must have wanted access to the latest news as it was crucial to their operations.

When it comes to the number of reports received directly from PolandLithuania, which amounts to $15 \%$ of all identified, one should not be surprised by what seems to be a rather low number. The situation where only a relatively small number of reports dealing with a specific country were in fact coming from that place was quite typical for the period. Even in the case of English news published in Antwerp in the 1620s, only about $40 \%$ of reports came from England, in spite of the relatively small distance and the existence of regular postal services. ${ }^{43}$

As far as the speed with which Polish news was transferred to England is concerned, it seems that the average time required to pass it along was between 4 and 7 weeks, but of course the origins of a given report, weather conditions, and sometimes its contents as well, were crucial factors here. Unsurprisingly, if the report was sent from Constantinople - either directly or via Venice - it was usually at least 6 to 7 weeks (and sometimes much longer) before it was published, while news of the visit of a Polish prince to the Netherlands could have been presented to readers within 10 days. ${ }^{44}$ In the case of reports coming directly from Poland-Lithuania, it appears that whether they were coming from news hubs like Danzig or from other cities, it could take a similar time for them to reach London. Two reports on Sigismund III's death are a good illustration of this. The first is datelined from Warsaw on 29 April 1632 New Style and reports that the king died the same day, and the other is datelined from Danzig on 4 May (no information was given whether it was Old or New Style date, but it must have been dated according to the Julian calendar). They were published

43 Arblaster, "Posts, Newsletters, Newspapers", p. 25.

44 For example a report on Wladyslaw's visit to Breda, datelined from Middleburg on 5 October 1624, was printed on page 11 of The continuation of of $[$ sic $]$ the weekly newes... (Dahl 150), issued also on 5 October. This means that it must have been dated according to the New Style and that it took exactly 10 days between it being written and being printed. 
on the 6th and the 23rd of June respectively, which means that each of them took about 50 days to reach London and be published. ${ }^{45}$ However, sometimes a report could arrive in London just after the publication of the most recent coranto and therefore would not be printed before the next number was issued, which, depending on situation, could have taken place within a few days, a week, almost two weeks, or even longer.

One must also remember that it was pretty typical for the corantos not to inform readers whether the reports were dated according to the Old or New Style, which, of course, illuminates another difficulty for researchers. ${ }^{46}$ Even though the New Style was already in use in Poland-Lithuania (since 1582) it was not uncommon for foreigners, as well as citizens of Prussian Cities, to use sometimes either dual or Old Style dating. This was also the case for reports from other Catholic countries that had accepted the Gregorian calendar, sometimes even from Rome itself, as they could have been dated according to the Old Style. ${ }^{47}$ As a result we are often left guessing at what the actual date of the report could be.

Similarly, one can only guess when it comes to a detailed identification of sources of information. Just as in the case of news from other countries, news dealing with Poland-Lithuania must have come from all kinds of continental materials (printed publications, newsletters, correspondence, etc.) traditionally used as sources by the London publishers. This is confirmed by phrases like "letters from Vienna," "they write from Prague," "we hear from Danzik," or "Wee have tidings out of Polania," used to introduce news items from the Continent. Situations where it was clearly indicated what kind of source materials had been used for a report were rather rare, but did happen nonetheless. In early 1623, The newes of forraine partes...quoted letters from Hungary as the basis for a report received from Vienna dealing with Bethlen Gabor's planned marriage to a "Polonian Princesse of Iarislaw."48 Just a few weeks later the readers of

45 The continuation of our forrine avisoes, 6 June 1632 (Dahl 274), p. 4; The continuation of our forraine avisoes, 23 June 1632 (Dahl 277), p. 3.

46 Boys, London's News Press, p. 47.

47 This can be illustrated by another report on the Polish prince's European journey. The Polish sources confirm that he arrived in Modena on 5 December 1624, while the report from Rome recording his visit to this city, gave the date of 25 November, which clearly indicates that it was dated according to the Old Style. The continuation of the weekly newes..., 5 January 1625 (Dahl 160), p. 2. See also A. Przyboś (ed.), Podróż królewicza Wtadystawa Wazy do krajów Europy Zachodniej w latach 1624-1625 (Kraków: Wydawnictwo Literackie, 1977), p. 226.

48 The newes of forraine partes, 28 February 1623 (Dahl 100), pp. 10-11. On Bethlen Gabor's planned marriage see also A relation of the late horrible treason..., 19 February 1623 (Dahl 99), p. 29. 
another coranto were informed that a report from Prague discussing the current political situation and Sigismund's diplomatic plans, was based on "the Polonian poast" that had recently passed "by their Citie to go towards Regensburg, to present the Emperour with these tidings." ${ }^{49}$

Apart from Sir Thomas Roe, who supplied editors with Turkish news, no particular person was named as their informant. Just once was it made clear that a piece of news - that the Polish king was keen on recruiting some English and Irish soldiers - was sent to England via Lübeck and Hamburg by merchants living in Cracow and Sandomierz, who we can assume were either English or Scots, as people of both nations lived in these two cities. Neither this fact, nor the character of their activities in Poland, were, however, clarified in the report. ${ }^{50}$ The detailed character of reports on the Polish-Swedish war between 1625 and 1628, suggests that at least some of them could have come from Swedish soldiers (again probably English and Scottish officers fighting under Gustavus Adolphus), ${ }^{51}$ but those could also have been provided by other channels.

We do not know who provided the editors with the description of Sigismund III's death, datelined from Warsaw. Its contents would suggest that this was a person close to the court who acted as an editor's correspondent, but it is still unclear, especially as there had been no previous direct regular influx of news from the Polish capital. Likewise, information about the Polish Protestants' support of Gustavus Adolphus's candidacy for the Polish throne in 1632 could imply that the news had originated from their circles - they did try to use it to strengthen their position before the election - but this cannot be confirmed.

But what does it all mean in more general terms? There is no doubt that the corantos played an important role in shaping the way Poland-Lithuania was perceived in England in the early seventeenth century, as they were a popular source of information for the English public. The picture they presented can be described as comprehensive, albeit not free from some stereotypical opinions, e.g. about the role of the Catholic Church and the Jesuits, who were often believed to act in a malignant way in order to suppress Protestantism. This stereotyping tendency, however, was typical for the early modern press in

49 The continuation of our former newes, 24 April 1623 (Dahl 108), p. 11.

50 The wonderfull resignation of Mustapha and the advancing of Amarath..., 11 November 1623 (Dahl 133), p. 6. This is the only case when the route of the report from Poland could be followed in such a detailed way.

51 Dauvit Horsbroch, "Wish you were here? Scottish Reactions to 'Postcards' Home from the Germane Warres” in S. Murdoch (ed.), Scotland and the Thirty Years' War, 1618-1648 (Leiden and Boston: Brill, 2001), pp. 246-247, p. 250. 
general. We also must not forget, that coranto editors showed strong proProtestant sympathies. ${ }^{52}$

There was also a pretty clearly visible evolution of the way the news from or dealing with Poland-Lithuania was presented to the English reading audience. Although initially it was more focused on simply covering the events, from the mid-1620s onwards the context in which the Polish-Lithuanian Commonwealth was reported on became much more complex.

The reports on Poland's relations with her neighbours - including Sweden, Turkey, and Transylvania - and also her domestic politics, show that these relations and politics were now all believed to be factors that could potentially affect Gustavus Adolphus's and/or Bethlen Gabor's ability to support the Protestant cause, and the Habsburgs' ability to harm their opponents. In other words, they could potentially have a significant impact, not only locally, but also on a much wider international level. As the developments of the Thirty Years' War were extremely important for English readers, this could have triggered additional interest in the Polish-Lithuanian Commonwealth. This remained unchanged until 1632, and again, when the publication of corantos was resumed in the late 1630s, the few Polish reports that were printed between 1638 and 1641 were of a very similar nature. Additionally, the domestic situation in England in 1620s could have been crucial for the editors' decisions to provide their readers with more detailed information on the political life of another country where relations between the monarch and his subjects were far from amicable due to the king's position on foreign policy and religious issues. This evolution might also have been a result of the changes corantos had been undergoing as a genre during the early 1620 s, but it does not seem to be the decisive factor in this particular case.

The presence of Polish news in the corantos proves that by the 1620s, in spite of all possible impediments, Poland-Lithuania was already a part of the larger pan-European system, consisting of interfacing networks making it possible to transmit news on a pretty regular basis from one part of the Continent to another. In the particular case of the English press, these were either private networks such as Sir Thomas Roe's reports and the news that was probably sent by military men active in Prussia - or more established and institutionalized ones. We cannot name precisely all of the kinds of materials originating in Danzig that were used by the editors, but we can guess that these might have included press publications, as the city had developed its own press market..$^{53}$ However, when

\footnotetext{
52 Raymond, Pamphlets and Pamphleteering, p. 136.

53 Jan Lankau, Prasa Staropolska na tle rozwoju prasy w Europie 1513-1729 (Kraków:

Państwowe Wydawnictwo Naukowe, 1960), pp. 92-94.
} 
we look at the reports datelined from Danzig that touch on Polish political life, for example discussing recent incidents during the Sejm's sessions, it is apparent that they are based on the accounts prepared for the City Council and circulated widely among the public. ${ }^{54}$

One must not forget that sometimes it is a combination of factors that needs to be taken under consideration. The large numbers of reports datelined from Vienna, Prague, and Silesia, and the 'internationalization' of Polish news contexts, could have resulted both from the fact that the situation in the Habsburg dominions was of interest to English readers, and from the fact that the PolishLithuanian Commonwealth was geographically close and linked to the same news networks, including the well-established Reichpost system that provided London editors with news on the latest development in the Thirty Years, War. ${ }^{55}$ These influences are not necessarily mutually exclusive.

These links were not strong enough to secure a more regular direct inflow of information from the Polish-Lithuanian state to London in the 1620 s and 1630 s, but they could have added to the interest in this country that can be observed in England in this period. It was more than a decade and took some further significant changes in the functioning of news networks in East-Central Europe, before an English audience was able to read the first direct regular weekly reports covering a wide spectrum of events in Poland-Lithuania. This, however, would have been far less likely to have come to pass, had there been no "tidings out of Polonia" printed in London corantos prior to this.

54 Jan Pirożyński, "Die Stellung der polnischen Metropolen im europäischen Nachrichtenverkehr des 16. Jahrhunderts" in Andrea Langer and Georg Michels (eds.), Metropolen Und Kulturtransfer Im 15./16. Jahrhundert.: Prag - Krakau - Danzig - Wien (Stuttgart: Franz Steiner Verlag, 2001), p. 105; Kazimierz Maliszewski, “Gdańsk jako ośrodek transferu informacji i komunikacji społecznej w Rzeczypospolitej szlacheckiej w XVII-XVIII wieku" in S. Salomonowicz (ed.), Mieszczaństwo Gdańskie (Gdańsk: Gdańskie Towarzystwo Naukowe, 1997), pp. 228-229.

55 Behringer, “Communications Revolutions”, pp. 345, 352-353; Boys, London's News Press, pp. 38, 40 . 